\section{EXPERIMENTAL STUDIES ON THE THRESHOLD OF VEHICLE INSTABILITY IN FLOODWATERS}

\author{
Syed Muzzamil Hussain Shah, Zahiraniza Mustaffa*, \\ Khamaruzaman Wan Yusof \\ Department of Civil and Environmental Engineering, Universiti \\ Teknologi PETRONAS, 32610, Seri Iskandar, Perak, Malaysia
}

Article history

Received

14 June 2017

Received in revised form

2 March 2018

Accepted

30 March 2018

Pubished online

1 August 2018

*Corresponding author zahiraniza@utp.edu.my

\section{Graphical abstract}

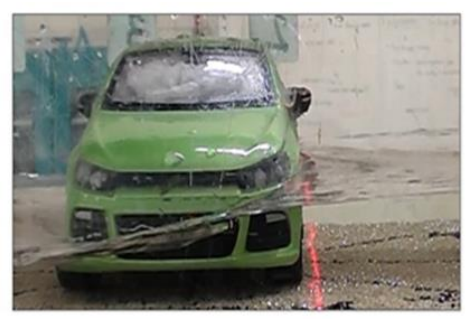

\begin{abstract}
Flood risks concerned to vehicle's instability have become more conspicuous and it is thus necessary to understand the behaviour of vehicles exposed to floodwaters. Therefore, this paper aims at investigating the thresholds of vehicle instability in floodwaters at different orientations. A stationary die-cast model vehicle $(1: 24)$ was used with the condition of rear tires being locked only, positioned at different orientation angles on a flat road surface in the partially submerged zone. Measurements were taken including the approaching velocities and water depths, through which the instability was computed. The study concludes that a partially submerged vehicle becomes instable at high water depths and low flow velocities and vice versa. Further, the vehicle was observed to be most stable when positioned at orientation angle of $0^{\circ} / 360^{\circ}$, with the limiting depth $\times$ velocity $\left(D^{*} V\right)$ value of $0.0168 \mathrm{~m}^{2} / \mathrm{s}$. On the other hand, it was noted to be least stable when positioned at the orientation angle of $90^{\circ}$ and $270^{\circ}$, with the limiting $\left(D^{*} \mathrm{~V}\right)$ value of $0.0144 \mathrm{~m}^{2} / \mathrm{s}$. The outcomes from this study were later translated into guidelines.
\end{abstract}

Keywords: Instability threshold, partially submerged vehicle, stationary vehicle, flat surface, guidelines

\begin{abstract}
Abstrak
Ketidakstabilan kenderaan di dalam banjir didapati telah menjadi perkara yang serious, maka adalah perlu untuk mengetahui situasi ini dengan lebih mendalam. Artikel ini bertujuan untuk mengenal pasti syarat-syarat kedalaman air dan halaju apabila sesuatu kenderaan menempuh air banjir. Sebuah kenderaan model 'die-cast'yang tidak bergerak (1:24) dan separa tenggelam telah digunakan dengan keadaan tayar belakang sahaja dikunci, dan diletakkan pada orientasi yang berbeza-beza sudut di atas permukaan jalan yang rata. Ukuran yang diambil termasuklah halaju dan kedalaman apabila ketidakstabilan terjadi. Kajian ini menyimpulkan bahawa sesuatu kenderaan separa tenggelam menjadi tidak stabil pada kedalaman air yang tinggi dan halaju aliran rendah dan sebaliknya. Di samping itu, kenderaan adalah paling stabil apabila diletakkan pada sudut orientasi $0^{\circ} / 360^{\circ}$, dengan kedalaman $\times$ halaju mengehadkan $\left(D^{*} \mathrm{~V}\right)$ bernilai $0.0168 \mathrm{~m}^{2} / \mathrm{s}$. Manakala, kenderaan berada kurang stabil apabila diletakkan pada sudut orientasi $90^{\circ}$ dan $270^{\circ}$, dengan pengehad $\left(D^{*} \mathrm{~V}\right)$ bernilai $0.0144 \mathrm{~m}^{2} / \mathrm{s}$. Hasil kajian ini akan menjadi garis panduan yang akan di cadangkan.
\end{abstract}

Kata kunci: ambang ketidakstabilan, kenderaan separa tenggelam, kenderaan pegun, permukaan rata, garis panduan 


\subsection{INTRODUCTION}

Peninsular Malaysia is an interesting example of rising flood hazard and disaster potential. Globally, rapid urbanization and land-use changes are believed to be major factors in rising disaster potential, especially in rapidly expanding nations, of which Malaysia is an example [1]. Regardless of the risk of periodic flooding, settlements have always been colonised on flood plains despite of several risks. These risks have been neglected mainly due to social and economic benefits (trading advantage), and environmental benefits of a riverbank location (fertile agricultural land). Early riverside settlements were on the local elevated areas or where the channel abuts higher ground on edge of flood plain. Later, the extensions of those towns encroached into the flood plain zones as shown in Figure 1 [2].

Floodwaters have potential to cause great damage. When people, vehicles, and even buildings are in the path of flood waters they can be susceptible to being lifted, pushed, and rolled along by the flood flows. In the simplest terms, the damage and danger that flood waters might cause can be related to the force of the flood flows as they travel down a floodplain. The force of floodwaters can be described by the flow depth and velocity that the flows are travelling at. Flood flows in nature always seek to move in the lowest energy condition, which is slow and deep rather than fast and shallow [3].

Roads are often the first assets influenced by inundations which make rescue operations challenging and represent a major threat to lives: almost half of the sufferers are car passengers trapped by floods [4]. Flood waters can be abruptly interrupted and adopt highly critical regimes along the road crossings which could alter the morphological conditions of the channel and increase the threats around these structures. This could be due to the improper drainage or when the amount of water arriving on the road is higher than the drainage capacity which usually ends up as a serious hazard to the traffic [5].

In recent years, the probability of flood occurrence has raised due to the considerable change in the meteorological system which has increased the risk of vehicle instability in floodwaters on causeways and streets [3]. A clear illustration of the similar damages is the heavy downpour which caused a devastating flash flood at the low-lying areas near Sungai Pinang and Sungai Air Itam in Penang, Malaysia on 15th September 2017 as shown in Figure 2. The department of Irrigation and Drainage (DID), Malaysia reported that both rivers, Sungai Pinang and Sungai Air Itam have reached the highest levels at $3.2 \mathrm{~m}$ and $7.3 \mathrm{~m}$, with rainfall of $198 \mathrm{~mm}$ and $120.5 \mathrm{~mm}$, respectively. Massive traffic gridlock at the roads was witnessed due to the submergence of the vehicles in floodwaters as most of the areas were flooded between $0.1 \mathrm{~m}$ to $0.6 \mathrm{~m}[6]$.
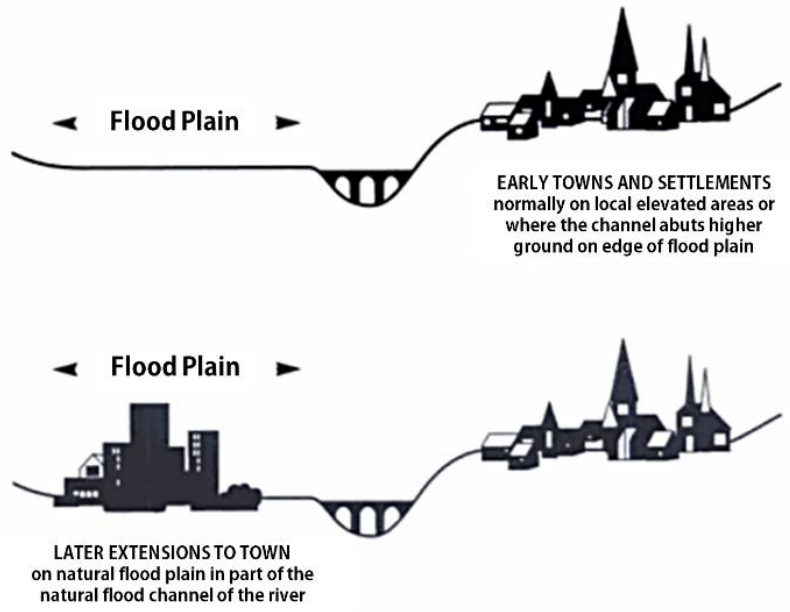

Figure 1 Floodplain encroachment

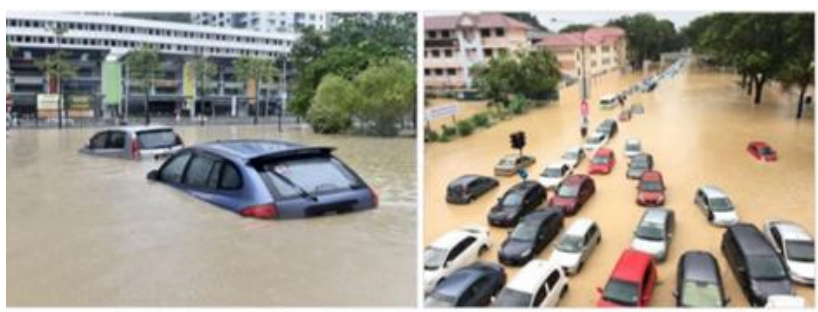

Figure 2 Flooded vehicles in the 2017 George Town, Penang (Malaysia) flood

Although, majority of the flood related deaths have happened in the developing nations but larger part of the studies is restricted to the US, with a couple in Europe and Australia [7]. It has been expressed that very little past work has been accounted for flood water flows over urban areas with vehicles [8]. The past floods experience, especially in Unites States, demonstrates that a typical danger that causes genuine harm to individuals is because of the instability of vehicles in floodwaters [9]. In majority of the events, flood water level is quickly raised and very less time is given to the people for their evacuation [10] thus, drowning is believed to be the substantial reason of demises during inundations [7]. Almost 2/3 of the fatalities that happen in floods occurs due to it [11]. It has been further expressed that human conduct is one of the element that adds to the flood casualty rates, as individuals tend to purposefully drive through the overwhelmed zones by disregarding dangers, for example, belittling notices and overlooking warnings [12] and get stuck in the flood water or swept away due to buoyancy force [13].

Table 1 shows the percentage of fatalities reported in vehicle during the flood events in different regions of the World that is Monterrey, Mexico [7], United States and Texas [14], Languedoc- Roussillon Region France [15], Europe and United States [11], and Australia [7]. 
Table 1 Vehicle Related Fatalities during Floods

\begin{tabular}{|c|c|c|c|}
\hline \multicolumn{4}{|c|}{ Monterrey, Mexico } \\
\hline Year & \multicolumn{2}{|l|}{ Cause } & $\begin{array}{ll}\text { No. } & \text { of } \\
\text { Mortalities }\end{array}$ \\
\hline 1988 & \multicolumn{2}{|c|}{ Crossing the flooded river } & $160 / 200$ \\
\hline \multicolumn{4}{|c|}{ Flood-Related Fatalities in United States of America } \\
\hline Year & $\begin{array}{l}\text { Total No. } \\
\text { of } \\
\text { Fatalities }\end{array}$ & $\begin{array}{l}\text { No. of Vehicle } \\
\text { Related Fatalities }\end{array}$ & $\begin{array}{l}\text { Percentage of } \\
\text { Vehicle } \\
\text { Related } \\
\text { Fatalities } \\
\end{array}$ \\
\hline 2006 & 76 & 32 & $42 \%$ \\
\hline 2005 & 43 & 18 & $42 \%$ \\
\hline 2004 & 82 & 45 & $54 \%$ \\
\hline 2003 & 86 & 39 & $45 \%$ \\
\hline 2002 & 49 & 28 & $57 \%$ \\
\hline 2001 & 48 & 24 & $50 \%$ \\
\hline 2000 & 38 & 24 & $63 \%$ \\
\hline Avg. & 60.3 & 30.0 & $49.7 \%$ \\
\hline \multicolumn{4}{|c|}{ Flood-Related Fatalities in Texas } \\
\hline Year & $\begin{array}{l}\text { Total No. } \\
\text { of } \\
\text { Fatalities }\end{array}$ & $\begin{array}{l}\text { No. of Vehicle } \\
\text { Related Fatalities }\end{array}$ & $\begin{array}{l}\text { Percentage of } \\
\text { Vehicle } \\
\text { Related } \\
\text { Fatalities }\end{array}$ \\
\hline 2006 & 8 & 4 & $50 \%$ \\
\hline 2005 & 3 & 2 & $67 \%$ \\
\hline 2004 & 14 & 13 & $93 \%$ \\
\hline 2003 & 2 & 2 & $100 \%$ \\
\hline 2002 & 14 & 9 & $64 \%$ \\
\hline 2001 & 9 & 8 & $89 \%$ \\
\hline 2000 & 9 & 8 & $89 \%$ \\
\hline Avg. & 8.4 & 6.6 & $78.6 \%$ \\
\hline
\end{tabular}

Flash Floods in Languedoc- Roussillon Region France

\begin{tabular}{llll}
\hline Year & Cause & No. of Mortalities \\
\hline $\begin{array}{lll}\text { Last } 50 \\
\text { years }\end{array}$ & $\begin{array}{l}\text { Vehicle } \\
\text { fatalities }\end{array}$ & related & $40 \%$ \\
\hline
\end{tabular}

\begin{tabular}{llllll}
\hline \multicolumn{5}{l}{ Flood-Related Fatalities in Australia } & \\
\hline Year & $\begin{array}{l}\text { No. of } \\
\text { Mortalities }\end{array}$ & $\begin{array}{l}\text { In } \\
\text { Vehicle }\end{array}$ & $\begin{array}{l}\text { On } \\
\text { Foot }\end{array}$ & $\begin{array}{l}\text { Recreational } \\
\text { Pursuits } \\
\text { (swimming) }\end{array}$ & $\begin{array}{l}\text { In } \\
\text { House }\end{array}$ \\
\hline $\begin{array}{l}\text { Over } \\
\text { the }\end{array}$ & & & & & \\
last & 169 & $31 \%$ & 17 & $15 \%$ & $12 \%$ \\
50 & & & $\%$ & & \\
years & & & & & \\
\hline
\end{tabular}

\begin{tabular}{|c|c|c|c|c|}
\hline \multicolumn{5}{|c|}{$\begin{array}{l}\text { Distribution of the causes and circumstances of death for the } \\
13 \text { events from Europe and America }\end{array}$} \\
\hline & $\begin{array}{l}\text { Cause of } \\
\text { death and the } \\
\text { surrounding } \\
\text { circumstances }\end{array}$ & $\begin{array}{l}\text { Total No. } \\
\text { of } \\
\text { Fatalities }\end{array}$ & $\begin{array}{l}\text { Total Deaths } \\
\text { Percentage }\end{array}$ & $\begin{array}{l}\text { Aggreg } \\
\text { ate }\end{array}$ \\
\hline \multirow{5}{*}{$\begin{array}{l}\text { Drow } \\
\text { ning }\end{array}$} & $\begin{array}{l}\text { As } \\
\text { pedestrian }\end{array}$ & 62 & $25.1 \%$ & \multirow{5}{*}{$\begin{array}{l}\text { All } \\
\text { drowni } \\
\text { ngs } \\
167 / 24 \\
7 \\
(67.5 \%)\end{array}$} \\
\hline & In vehicle & 81 & $32.8 \%$ & \\
\hline & From boat & 07 & $2.8 \%$ & \\
\hline & $\begin{array}{l}\text { During } \\
\text { rescue } \\
\text { attempt }\end{array}$ & 02 & $0.8 \%$ & \\
\hline & In building & 15 & $6.1 \%$ & \\
\hline
\end{tabular}

Hydrodynamic forces caused by the flowing water, particularly floodwaters flows can move vehicles on urban floodplains as shown in Figure 3. An understanding of the relevant forces involved, namely, effective vehicle weight $\left(\mathrm{F}_{\mathrm{G}}\right)$, frictional force $\left(F_{R}\right)$, buoyancy force $\left(F_{B}\right)$, lift force $\left(F_{L}\right)$, normal reaction force from ground $\left(\mathrm{F}_{\mathrm{N}}\right)$, and drag force $\left(\mathrm{F}_{\mathrm{D}}\right)$ is necessary to attempt to characterize the stability threshold of vehicles in flood water flows.

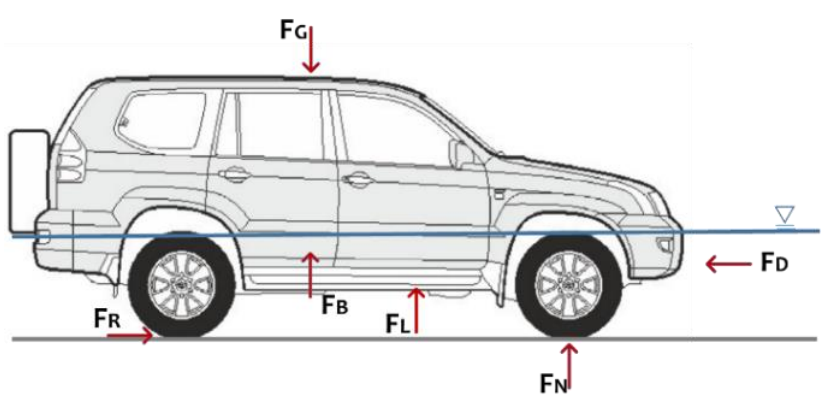

Figure 3 Forces on the vehicle in floodwater

The friction force is the primary hydrodynamic force that acts between the floodplain surface and the vehicle tires. This force is the total resistance acting on the vehicle tires by the floodplain surface which prevents the vehicle from sliding. Once the vehicle is lifted off from the surface the friction force becomes zero. The friction force can be expressed as:

$$
\mathrm{F}_{\mathrm{R}}=\mu \mathrm{F}_{\mathrm{G}}
$$

where, $\mu$ is the friction coefficient, set at 0.3 after Bonham and Hattersley (1967), and $\mathrm{F}_{\mathrm{G}}$ is the effective vehicle weight [8].

The effective vehicle weight can be determined by deducting the buoyancy and lift forces from the total weight of the car (in dry condition). It can be expressed as:

$$
\mathrm{F}_{\mathrm{G}}=\mathrm{F}_{\mathrm{N}}=\mathrm{W}_{\mathrm{T}}-\left(\mathrm{F}_{\mathrm{B}}+\mathrm{F}_{\mathrm{L}}\right)
$$


where, $\mathrm{W}_{\mathrm{T}}$ is the total weight of the vehicle in dry condition, $F_{B}$ is the buoyancy force and $F_{L}$ is the lift force [16]. For high flow velocities, the effect of buoyancy could be neglected, thereby considering only the effect of lift force [17]. Herein, the study was performed under the sub-critical flow conditions thus, the influence of lift force was disregarded.

The buoyancy force is an upward force exerted by a fluid that opposes the weight of the immersed object. In case of stationary model vehicle, when the buoyancy force is greater than the vehicle weight then the vehicle will be carried away by the flow. The buoyancy force can be expressed as:

$$
\mathrm{F}_{\mathrm{B}}=\rho g \mathrm{~V}
$$

where, $\rho$ is the density of water, $g$ is the acceleration due to gravity, and $\mathrm{V}$ is the submerged volume of the vehicle [18].

In fluid dynamics, drag acts opposite to the relative motion of any object moving with respect to a surrounding fluid. The drag force relies on the area of changing momentum, fluid velocity and its density. This force can be expressed as:

$$
\mathrm{F}_{\mathrm{D}}=\frac{1}{2} \rho \mathrm{C}_{\mathrm{D}} A v^{2}
$$

where, $F_{D}$ is the drag force, $\rho$ is water density, $C_{D}$ is the coefficient of drag, $\mathrm{A}$ is the submerged area perpendicular to the flow direction, and $\mathrm{v}$ is the flow velocity [8].

The hydrodynamic mechanisms by which the vehicle stability is lost can be recognized either by floating, sliding and toppling instability as shown in Figure 4. Floating instability occurs when the buoyancy force exerted by water exceeds the vehicle weight. This type of instability usually occurs when the flow depth is high and the velocity is low. On the other hand, sliding instability takes place when the horizontal force i.e. drag force applied by water on one or more vehicle panels exceeds vertical restoring force which relies on the friction between the road surface and car tires, vehicle mass and buoyancy. A further mode of instability which occurs due to overturning is called toppling instability. However, this stability appears to be restricted to vehicles which are already sliding or floating. Therefore, it has been excluded in the current investigation from further consideration [19].

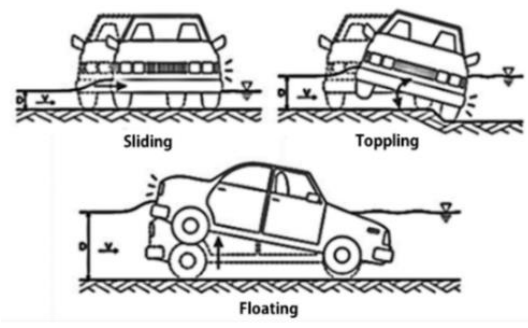

Figure 4 Modes of vehicle instability
The existing design guidelines and recommendations proposed for the limits of vehicle stability to be based on the products of flow depth (D) and velocity (V) derived during the experimental studies conducted in the late 1960's and early 1970's (Bonham and Hattersley, 1967; Gordon and Stone, 1973), and theoretical analysis in the early 1990's (Keller and Mitsche, 1993). These guidelines are practicing the same as there was no significant research published in the field of vehicle stability in the intervening period between Keller and Mitsche's work (1993) and Teo et al.'s work (2010). However, today's vehicle on roads are more aerodynamic with a higher sealing capacity. Therefore, during flooding these vehicles become easily buoyant thus, the results of these earlier studies may no longer hold for contemporary vehicles and cannot be adopted permanently [19]. Herein, a comprehensive explanation of previous studies is highlighted which is further classified into theoretical and experimental studies.

Bonham and Hattersley (1967) conducted a laboratory testing on the stability of a model Ford Falcon. The concern of the study was to ascertain the performance of the motor vehicle on the flooded area. The study suggests that the reaction between tires and road surface is reduced due to the buoyancy force, with lateral pressure generated by the flow against the side of the car. When this lateral pressure exceeds the maximum frictional resistance developed by the car tires, the car begins to proceed. The study proposed the coefficient of friction $(\mu)$ of 0.3 using the resultant equation of stability as:

$$
\frac{\mathrm{F}_{\mathrm{H}}}{\mu \mathrm{F}_{\mathrm{V}}}=1
$$

Where, $\mathrm{F}_{\mathrm{H}}$ is the force in the horizontal direction and $\mathrm{F}_{\mathrm{V}}$ is the force in the vertical direction [20].

Gordan and Stone (1973) conducted a similar laboratory testing on the stability of model Morris Mini using the same resultant equation of stability and proposed range of coefficients between $\mu=0.3$ to $\mu=1$.0. The results attained indicate that the stationary value of $\mu=0.3$ assumed by Bonham and Hattersley (1967) is likely conservative [21].

Keller and Mitsch (1993) conducted a purely theoretical study on the instability criteria of different vehicles in floodwater, including, Suzuki Swift, Ford Laser, Toyota Corolla, and Ford LTD. The study outcomes presented a procedure for estimating the relationship between the corresponding critical velocity and the water depth. This analysis provided a fundamental approach for determining the forces exerted on parked vehicles in flood water and proposed the incipient velocity formula for the vehicles in partially submerged condition as given below:

$$
\mathrm{v}=2 \sqrt{\frac{\mu \mathrm{F}_{\mathrm{V}}}{\rho \mathrm{C}_{\mathrm{D}} \mathrm{A}}}
$$

where, $\mathrm{v}$ is the velocity at the threshold of instability of each vehicle, $\mu$ is the coefficient of friction assumed as $0.3, F_{V}$ is the force in vertical direction, $\rho$ is the 
density of water, $C_{D}$ is the drag coefficient assumed to be 1.1 on wheels and 1.15 on the vehicle body with no sensitivity assessment evident, and $\mathrm{A}$ is the projected area normal to the flow [22].

Mens et al., (2008) conducted a theoretical testing on the instability of Vans, Ambulance, Car, and Fire Engines shown in Figure 5. The study concluded that as the water depth increases, the velocity required to make a vehicle instable decreases. This is because the downward force of the vehicle is countered by increased buoyancy. When the flood depth is greater than the chassis height, a large amount of water is displaced and stationary vehicle will float at a very shallow depth. The study further illustrate that the stability of a vehicle is influenced by the vehicle mass, dimensions, drag force, and buoyancy. The vehicle's instability at a particular velocity was determined by using the formula:

$$
\mathrm{v}=2 \sqrt{\frac{\mathrm{F}_{\mathrm{r}}}{\rho \mathrm{C}_{\mathrm{D}} \mathrm{A}_{\mathrm{tyre}} \mathrm{D}}}
$$

where, $v$ is the velocity at the threshold of vehicle instability, $F_{r}$ is the restoring force at the axle, $\rho$ is the density of water, $\mathrm{C}_{\mathrm{D}}$ is the drag coefficient which was assumed to be 1.1 if the water level is below the chassis and 1.15 if the water level is above the chassis, $A$ is the area of tires in contact with the ground, and D is the depth of flood water [23].

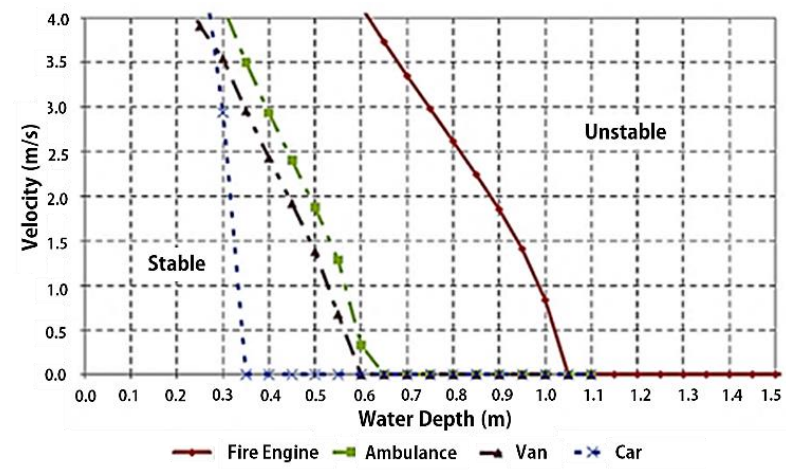

Figure $\mathbf{5}$ Vehicle stability curve as a function of velocity and water depth

Shand et al., (2010) recommended draft stability criteria for three vehicle classes, namely, small passenger, large passenger, and 4WD (four-wheel drives) vehicles. With the changes in the modern vehicle designs coupled by the limited nature of previous experimental works and lack of calibration in computational studies, it is unlikely that those previous results can be implemented directly when translated to the modern vehicles. Therefore, the draft stability criteria were proposed with the limiting depth and velocity $\left(D^{*} V\right)$ values. This was incorporated to provide agreement with human stability criteria presented within Cox et al., (2010) [24] and to assure that in case of vehicle instability, safety standards were not compromised once the people abandoned their vehicles. The equation of stability recommended for the small passenger, large passenger, and large 4WD vehicles can be given by:

$$
\mathrm{DV} \leq 0.3, \mathrm{DV} \leq 0.45, \text { and } \mathrm{DV} \leq 0.6
$$

where, $\mathrm{D}$ is depth and $\mathrm{V}$ is velocity of the flow [19].

Teo et al., (2010) investigated the hydraulic behaviours of vehicles on urban floodplains by conducting laboratory experiments in the hydraulic flume using rough bed surface. In searching for critical conditions for vehicle instability thresholds, the effects of the vehicle at different orientations were investigated following the conditions of sliding equilibrium. Two sets of different models, namely Mini Cooper, BMW M5 and Mitsubishi Pajero, with the scales of 1:43 (small scale) and 1:18 (large scale) were adopted. The experimental results obtained from the small-scale model (1:43) were then scaled up to the large scaled model using hydraulic similarity (predicted). These predicated results were then compared with the experimental results obtained for the large-scale model $(1: 18)$ to validate the results as shown in Figure 6 . The trends of the predicted values were in general agreement with the trends of the observed data ensuring that hydraulic similarity is capable of estimating the threshold values for the larger scale vehicles and for the estimation of prototype vehicles. The corresponding criterion of instability threshold is given by:

$$
\mathrm{V}=\left[\frac{2 \mu \mathrm{N}}{\rho \mathrm{C}_{\mathrm{D}} \mathrm{A}_{\mathrm{D}}}\right]^{\frac{1}{2}}
$$

where, $v$ is the velocity at the threshold of instability, $\mu$ is the coefficient friction, $\mathrm{N}$ is the axle load in wet conditions (also the axle load in dry conditions minus the buoyancy force on the vehicle, which is distributed on the front and rear axles according to the location of the center of buoyancy), $\rho$ is water density, $\mathrm{C}_{\mathrm{D}}$ is the coefficient of drag which was set at 1.1 if the water level is below the vehicle chassis and 1.15 if it is above the vehicle chassis, and $A_{D}$ is the submerged area perpendicular to flow direction [25].

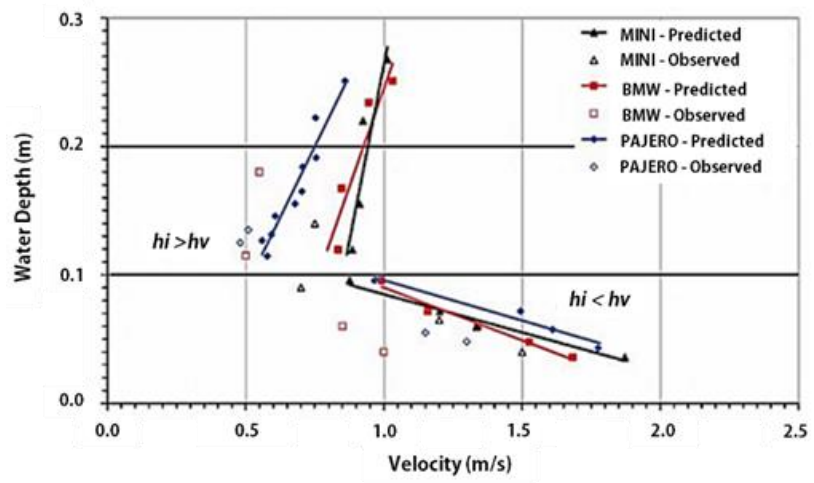

Figure 6 Validation of predicted results with observed data for 1:18 scaled models 
Xia et al., (2010) proposed a mechanism to predict the incipient velocity of flooded vehicles according to the mechanical condition of sliding equilibrium. The formula was proven based on the experimental investigations of Teo et al., (2010) for the three-tested small-scale vehicles models $(1: 43)$. The formula used to determine the incipient velocity is given by:

$$
\mathrm{U}_{\mathrm{c}}=\alpha \times\left(\frac{\mathrm{h}}{\mathrm{h}_{\mathrm{c}}}\right)^{\beta} \sqrt{2 \mathrm{~g}\left(\frac{\rho_{\mathrm{c}}-\rho_{\mathrm{f}}}{\rho_{\mathrm{f}}}\right) \mathrm{h}_{\mathrm{c}}}
$$

where, $U_{c}$ is the incipient velocity for the flooded vehicles, $\alpha$ and $\beta$ are the empirical parameters for each vehicle, $h$ is the water depth, $h_{c}$ is the vehicle height, $\rho_{\mathrm{c}}$ is the vehicle density and $\rho_{\mathrm{f}}$ is water density [26].

Shu et al., (2011) investigated the stability measures for the vehicles in partially submerged condition by deriving a mechanics based formula of incipient velocity for only two orientation angles that is $0^{\circ}$ and $180^{\circ}$. The flume experiments were conducted on the wet carpet using three types of die-cast vehicles $(1: 18)$, namely Ford Focus, Ford Transit, and Volvo XC90, closely following the criteria of geometric, kinematic, and dynamic similarity. The predicted velocities using the formula agreed well with the corresponding measured values with the correlation coefficient $R^{2}$ of 0.97 , ensuring that if the incoming flow depth is less than the vehicle height, then the threshold velocity increased for a decrease in the depth of flow as shown in Figure 7. The formula used to estimate the incipient velocity is given by:

$$
\mathrm{U}_{\mathrm{c}}=\alpha\left(\frac{\mathrm{h}_{\mathrm{f}}}{\mathrm{h}_{\mathrm{c}}}\right)^{\beta} \sqrt{2 \mathrm{~g}_{\mathrm{c}}\left(\frac{\mathrm{h}_{\mathrm{c}} \rho_{\mathrm{c}}}{\mathrm{h}_{\mathrm{f}} \rho_{\mathrm{f}}}-\mathrm{R}_{\mathrm{f}}\right)}
$$

where, $U_{c}$ is the incipient velocity for partially submerged vehicles in flood waters, $\alpha$ and $\beta$ are the empirical parameters for each vehicle, $h_{f}$ is the water depth, $h_{c}$ is the vehicle height, $l_{c}$ is the car length, $\rho_{c}$ is the vehicle density, $\rho_{\mathrm{w}}$ is the density of water and $\mathrm{R}_{\mathrm{f}}$ is the ratio of vehicle height and density to the buoyancy depth and water density [18].
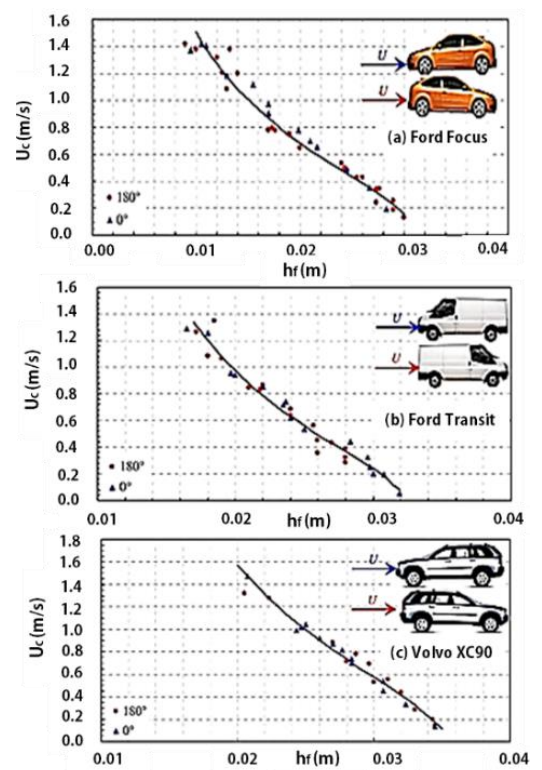

Figure 7 Depth-incipient velocity relationships for partially submerged model vehicles (a) ford Focus, (b) Ford Transit and (c) Volvo Xc90

Xia et al., (2013) conducted the flume experiments to obtain the conditions of water depth and corresponding velocity at the threshold of vehicle instability for three orientation angles, namely $0^{\circ}, 180^{\circ}$, and $90^{\circ}$ as shown Figure 8 at two ground slopes of 1:50 and 1:100, using two types of die-cast vehicles (Honda and Audi) at model scales of 1:14 and 1:24. The experimental runs were conducted on a thin cement layer. Results indicated that there was no substantial difference in the condition of incipient motion for the orientation angles of $0^{\circ}$ and $180^{\circ}$ because the submerged area projected normal to the incoming flow for the former was almost equivalent to that for the latter for a partially submerged vehicle. However, it was observed that at $90^{\circ}$, the incipient velocity required to make the vehicles instable was low for both the car models. The study further suggested that the incipient velocity required to make a car instable at different slopes is reduced as compared to the flat surface. When the ground slope is at angle $\theta$ then the driving force causing the vehicle to slip is increased and the value of normal force is reduced. Xia et al., (2013) modified the same equation as proposed by Shu et al., (2011) (applicable to vehicles positioned parallel to the flow direction) for the vehicles positioned perpendicular to the flow direction. Therefore, the proposed resultant equation of stability based on the mode of sliding stability can be given as:

$$
\mathrm{U}_{\mathrm{c}}=\alpha\left(\frac{\mathrm{h}_{\mathrm{f}}}{\mathrm{h}_{\mathrm{c}}}\right)^{\beta} \sqrt{2 \mathrm{~g}_{\mathrm{c}}\left(\frac{\mathrm{h}_{\mathrm{c}} \rho_{\mathrm{c}}}{\mathrm{h}_{\mathrm{f}} \rho_{\mathrm{f}}}-\mathrm{R}_{\mathrm{f}}\right)}
$$

where, $U_{c}$ is the incipient velocity for partially submerged vehicles in flood waters, $\alpha$ and $\beta$ are the empirical parameters for each vehicle, $h_{f}$ is the water depth, $\mathrm{h}_{\mathrm{c}}$ is the vehicle height, $\mathrm{b}_{\mathrm{c}}$ is the vehicle width, 
$\rho_{\mathrm{c}}$ is the vehicle density, $\rho_{\mathrm{f}}$ is the density of water and $\mathrm{R}_{\mathrm{f}}$ is the ratio of vehicle height and density to the buoyancy depth and water density [9].
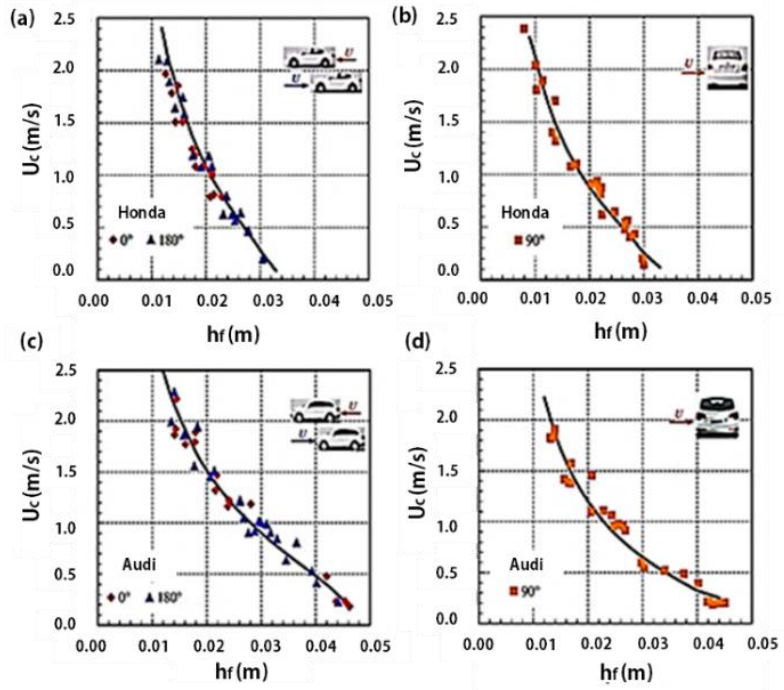

Figure 8 Depth-incipient velocity relationships for large-scale model vehicles for different orientation angles

Martínez-Gomariz et al., (2017) proposed a new approach by defining the stability thresholds for vehicles exposed to inundations by considering the analysis of both buoyancy and friction effects. The experiments were conducted in the flume of hydraulic laboratory of the Technical University of Catalonia (Spain) as shown in Figure 9. The resultant equation of stability proposed can be given as:

$$
\text { (v.y) }=0.0158 \cdot \mathrm{SC}_{\bmod }+0.32
$$

where, (v.y) is the stability threshold for each vehicle and $\mathrm{SC}_{\mathrm{mod}}$ is the modified stability coefficient which can be given as:

$$
\mathrm{SC}_{\mathrm{mod}}=\frac{\mathrm{G}_{\mathrm{C}} \cdot \mathrm{M}_{\mathrm{C}}}{\mathrm{PA}} \cdot \mu
$$

where, $\mathrm{G}_{\mathrm{C}}$ is the ground clearance, $\mathrm{M}_{\mathrm{C}}$ is the kerb weight, $\mathrm{PA}$ is the plan area, and $\mu$ is the friction coefficient [17].

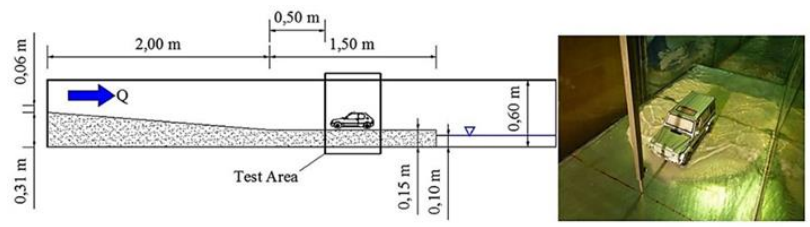

Figure 9 Experimental setup

From the available analytical and experimental data, it appeared that almost all studies were solely dedicated to static vehicles. For the partially submerged vehicles, it was noticed that at high water depths, low flow velocities were needed to cause the floating instability mode, whereas at low water depths, high flow velocities were needed for sliding instability to occur. It has been further identified that the surface roughness which is an important parameter to determine the vehicle instability in the flooding conditions has not been critically studied in the previous studies, thus, assuming either wetted carpet, rough bed surface, thin cement layer, etc. However, for this study the runs were conducted on a surface which nearly meets the Manning's surface roughness of a road pavement to ensure proper friction between the tires and the ground. Further, it was noticed that vehicle instability has been investigated at limited orientations in previous studies. Herein, the experimental investigations on the mode of instability at all orientations that is $0^{\circ}, 45^{\circ}, 90^{\circ}, 135^{\circ}$, $180^{\circ}, 225^{\circ}, 270^{\circ}, 315^{\circ}$ and $360^{\circ}$ were carried and guidelines, defining the limiting $\left(D^{*} \mathrm{~V}\right)$ values have been proposed.

\subsection{METHODOLOGY}

Today's vehicle on roads are different in design from the past, where new improvements in these vehicle design have taken into consideration. Therefore, in the current study a modern vehicle, Volkswagen Scirocco $R$ with the geometric scale ratio of 1:24 was selected. The purpose of the study was to observe the response of vehicle size, design shape, and weight on the thresholds of vehicle instability in the partially submerged flooding situation. The study was conducted under the conditions that (i) rear tires being locked and (ii) vehicle behaviours being tested for all orientation angles. Moreover, to prevent water from seeping into the inside space of a vehicle, its interior space was filled with light foam. In making the model vehicle to be water tight, its side door windows were covered with plastic.

The experimental runs were conducted in hydraulic flume located at Universiti Teknologi PETRONAS, Malaysia. The flume is $10 \mathrm{~m}$ long, $0.45 \mathrm{~m}$ deep, and $0.3 \mathrm{~m}$ wide as shown in Figure 10. The vehicle was placed on a platform. The water depth upstream of the vehicle was measured using a point gauge [27], while Nixon streamflo 430 was used for the velocity. Similarity principles were followed to determine the critical conditions for the model vehicle [25]. A monitoring laser was used to observe the movement of the vehicle in water at any displacements taken placed in the-x or -y directions.

Thresholds of vehicle instability of the model vehicle was observed in different orientations. The discharge in the flume was adjusted gradually and the corresponding averaged velocity and the incoming water depth was measured when either the floating or sliding instability was observed. 


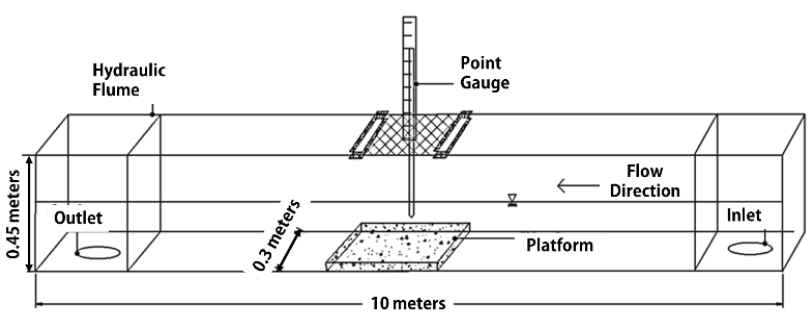

Figure 10 Schematic diagram of hydraulic flume

\subsection{RESULTS AND DISCUSSION}

Investigations on the hydrodynamics of floodplains with stationary scaled model vehicle was undertaken by conducting a series of experimental studies in the hydraulic flume. The purpose of the study was to observe the behaviour of partially submerged vehicles at all the orientations that is $0^{\circ}, 45^{\circ}, 90^{\circ}, 135^{\circ}, 180^{\circ}$, $225^{\circ}, 270^{\circ}, 315^{\circ}$ and $360^{\circ}$ in floodwater flows with the condition of rear tires locked as shown in Figure 11.

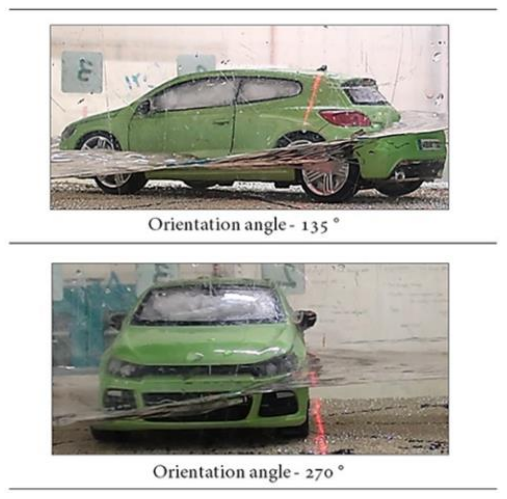

Figure 11 Model vehicle in different orientations

Several studies have been conducted using scaled model vehicle to determine the vehicle stability on floodplains and guidelines have been developed with regards to the hydrodynamic impacts of vehicles in floodplains. However, it has been noticed that the important parameter of surface roughness has been lightly considered. Studies carried on the wetted carpet [18] and thin cement layer [9] have different surface roughness when compared to the real road conditions. Therefore, prior to conducting the experiments it was necessary to determine the surface roughness of the platform where the experiments were conducted to assure proper friction between the vehicle tires and road surface. Therefore, for this study the surface roughness of the designed platform was first determined ensuring that it nearly matches with the normal road conditions. The results attained from the experimental runs states that the average Manning roughness for the designed platform was found to be 0.017 which nearly matches with the Manning's coefficient for asphalt pavements (rough texture - 0.016) [28]. This assured that the surface being used for the experimental runs provided nearly the same surface roughness as observed over the asphalt pavements as shown in Figure 12.

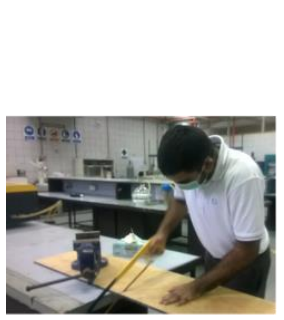

(a)

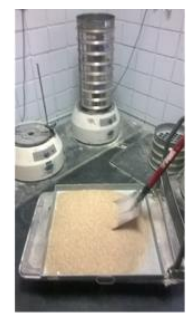

(b)

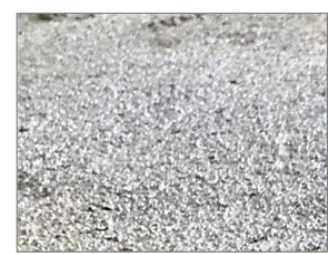

(c)
Figure 12 Surface roughness (a) cutting plywood, (b) sieve analysis and (c) designed platform

\subsection{Threshold of Vehicle Instability}

The thresholds of vehicle instability when the flooded vehicle started to move were found to be governed by the incoming flow velocity, water depth and discharges. The outcomes of the study agreed well with the previous studies [8], [18], [26], [29], and [30] with the indications that at high water depths, low flow velocity was needed, whereas at low water depths, high flow velocity was required to make a vehicle instable in the partially submerged condition. Since the scope of this paper is limited to partially submerged vehicles only, therefore, only points below $0.05825 \mathrm{~m}$ (height of the model vehicle) were studied. The results captured for all vehicle orientations are shown in Figure 13.

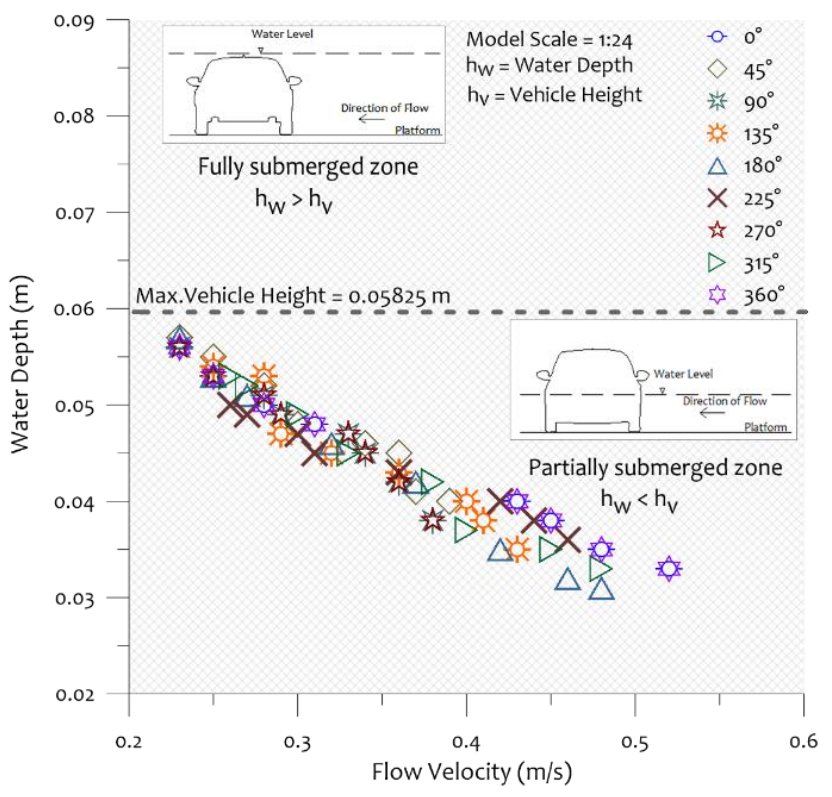

Figure 13 Threshold of vehicle instability

It was observed when the approaching water depths of the vehicle exceeded $0.042 \mathrm{~m}$, mode of floating instability had taken place. This happened as the vertical up-thrust force imposed by the fluid was 
greater than the vehicle weight. However, below this point, the stability of the model vehicle was completely relying on the dominancy of the friction or the drag force. At several combinations of flow velocity and water depth, the vehicle was found stable which happened as the drag force caused by the fluid was lower than the frictional force between the tires and the ground. Conversely, sliding instability occurred when the frictional force which relates to the friction coefficient and the net weight of the vehicle was lower than drag force caused by the flowing water.

Flood flows in nature always seek to move in the lowest energy condition, which is slow and deep rather than fast and shallow. In that context, it can be said that when the water depth approaching the vehicle exceeded $0.042 \mathrm{~m}$, flow velocity had nominal influence on the floating instability. On the other hand, below $0.042 \mathrm{~m}$, flow velocity was found dominant to cause the sliding instability. Since this study was observed with the condition of rear tires locked only, therefore, once the kinetic friction governed, sliding friction at the rear tires of the vehicle and rolling friction at the front tires of the vehicle were observed.

It has been stated that there is no substantial difference in the condition of incipient motion for the orientation angles of $0^{\circ}$ and $180^{\circ}$ because the submerged area projected normal to the incoming flow was almost equivalent in both the orientation for the partially submerged conditions [9]. However, while studying the effects of orientation on the threshold of vehicle instability, it was noticed that there was a considerable difference in the condition of incipient motion for both the orientations. The reason for which is suggested that when it comes to the drag force, it is always concerned to the submerged area projected normal to the flow. Therefore, at both the orientations, the submerged area at the same water depth differs. For example, at the orientation angle of $0^{\circ}$, when the incoming flow was above the front bonnet, the impact of drag was low due to the aerodynamic front shape and the smooth curve of the front bonnet car. Therefore, this orientation was found to be the most stable as the affected area of the vehicle by the influence of drag force was minimum. On the contrary, when the vehicle was at the orientation angle of $180^{\circ}$, it presented larger surface area thus, causing the larger impact of pressure drag on the vehicle. Therefore, the resultant force induced on the vehicle at $180^{\circ}$ when compared to $0^{\circ}$ was high as illustrated in in Figure 14.
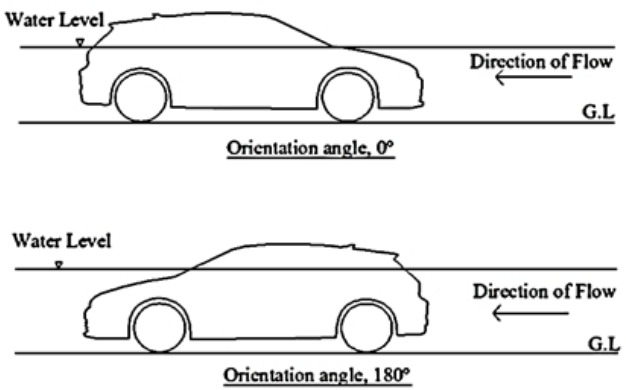

Figure 14 Observations for the orientation angle of $0^{\circ}$ and $180^{\circ}$

The model vehicle was observed to be least stable and the impact of drag was found maximum when it was placed perpendicular to the flow direction i.e. $90^{\circ}$ and $270^{\circ}$ as shown in Figure 15. The reason for the least stability is suggested to be the large bluff area projected normal to the flow when compared to the rear and front ends of the vehicle. This raised the blockage area and reduced the cross-sectional area of the flow through vehicle and subsequently increased the drag force which influenced the resistance of the vehicle through the water channel. Therefore, at this orientation smaller threshold velocity was sufficient to overcome the frictional force and thus, allowing sliding instability to govern.
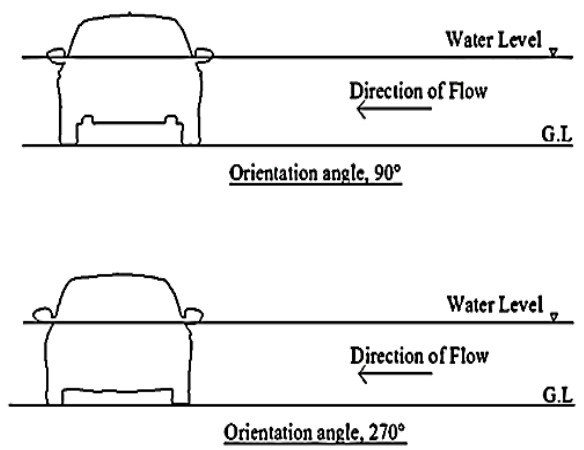

Figure 15 Observations for the orientation angle of $90^{\circ}$ and $270^{\circ}$

\subsection{Guidelines}

To ensure the stability of vehicles in the longitudinal and lateral flows and to prevent pedestrians from being swept away during major storm events, guidelines are usually recommended based on the limiting values of depth times velocity ( $\left.D^{*} \vee\right)$ [19]. Herein, the $D^{*} V$ values obtained for the model vehicle below critical water depth have been discussed as shown in Table 2. The $D^{*} \mathrm{~V}$ values in the table indicates that the vehicle was found to be most stable at the orientation of $0^{\circ} / 360^{\circ}$. Therefore, higher $\left(D^{*} \mathrm{~V}\right)$ values were needed to cause the mode of sliding instability. The lower threshold critical value obtained at this orientation was found to be $0.0168 \mathrm{~m}^{2} / \mathrm{s}$. Thus, it can 
be said that the proposed criteria of vehicle stability at $0^{\circ} / 360^{\circ}$ can be attained when DV $<0.0168 \mathrm{~m}^{2} / \mathrm{s}$. On the other hand, the least stable orientation was noticed at $90^{\circ}$ and $270^{\circ}$, as the mode of sliding instability was witnessed at very low $\left(D^{*} \mathrm{~V}\right)$ values. The lower threshold critical value obtained at this orientation was found to be $0.0144 \mathrm{~m}^{2} / \mathrm{s}$. Thus, for this orientation, the proposed criteria of vehicle stability can be suggested when DV $<0.0144 \mathrm{~m}^{2} / \mathrm{s}$. However, when the vehicle was at angles other than $0^{\circ} / 360^{\circ}, 90^{\circ}$ and $270^{\circ}$, the lower threshold critical $D^{*} \mathrm{~V}$ values were found to be $0.0152 \mathrm{~m}^{2} / \mathrm{s}, 0.0151 \mathrm{~m}^{2} / \mathrm{s}, 0.0147 \mathrm{~m}^{2} / \mathrm{s}$, $0.0166 \mathrm{~m}^{2} / \mathrm{s}$ and $0.0148 \mathrm{~m}^{2} / \mathrm{s}$ for $45^{\circ}, 135^{\circ}, 180^{\circ}, 225^{\circ}$ and $315^{\circ}$, respectively. These values were lower than the critical threshold value observed for the orientation of $0^{\circ} / 360^{\circ}$ but higher than the values observed at $90^{\circ}$ and $270^{\circ}$. The lower threshold critical values obtained for all orientations are shown in Figure 16.

Table $2 \mathrm{D} * \mathrm{~V}$ values below critical water depth

\begin{tabular}{|c|c|c|c|}
\hline $\begin{array}{c}\text { Vehicle } \\
\text { Orientation } \\
\left({ }^{\circ}\right)\end{array}$ & $\begin{array}{l}\text { Water } \\
\text { Depth } \\
(\mathbf{m})\end{array}$ & $\begin{array}{l}\text { Flow } \\
\text { Velocity } \\
(\mathbf{m} / \mathbf{s})\end{array}$ & $\begin{array}{c}\text { Depth x Velocity, } \\
\left(D^{*} V\right)\left(m^{2} / \mathrm{sec}\right)\end{array}$ \\
\hline $0^{\circ}$ & 0.035 & 0.48 & 0.0168 \\
\hline $0^{\circ}$ & 0.033 & 0.52 & 0.0172 \\
\hline $0^{\circ}$ & 0.038 & 0.45 & 0.0171 \\
\hline $0^{\circ}$ & 0.040 & 0.43 & 0.0172 \\
\hline $45^{\circ}$ & 0.040 & 0.39 & 0.0156 \\
\hline $45^{\circ}$ & 0.041 & 0.37 & 0.0152 \\
\hline $90^{\circ}$ & 0.038 & 0.38 & 0.0144 \\
\hline $90^{\circ}$ & 0.042 & 0.36 & 0.0151 \\
\hline $135^{\circ}$ & 0.040 & 0.40 & 0.0160 \\
\hline $135^{\circ}$ & 0.038 & 0.41 & 0.0156 \\
\hline $135^{\circ}$ & 0.035 & 0.43 & 0.0151 \\
\hline $180^{\circ}$ & 0.042 & 0.37 & 0.0155 \\
\hline $180^{\circ}$ & 0.035 & 0.42 & 0.0147 \\
\hline $180^{\circ}$ & 0.032 & 0.46 & 0.0147 \\
\hline $180^{\circ}$ & 0.031 & 0.48 & 0.0149 \\
\hline $225^{\circ}$ & 0.040 & 0.42 & 0.0168 \\
\hline $225^{\circ}$ & 0.038 & 0.44 & 0.0167 \\
\hline $225^{\circ}$ & 0.036 & 0.46 & 0.0166 \\
\hline $270^{\circ}$ & 0.038 & 0.38 & 0.0144 \\
\hline $270^{\circ}$ & 0.042 & 0.36 & 0.0151 \\
\hline $315^{\circ}$ & 0.042 & 0.38 & 0.0160 \\
\hline $315^{\circ}$ & 0.037 & 0.40 & 0.0148 \\
\hline $315^{\circ}$ & 0.033 & 0.48 & 0.0158 \\
\hline $315^{\circ}$ & 0.035 & 0.45 & 0.0158 \\
\hline $360^{\circ}$ & 0.035 & 0.48 & 0.0168 \\
\hline $360^{\circ}$ & 0.033 & 0.52 & 0.0172 \\
\hline $360^{\circ}$ & 0.038 & 0.45 & 0.0171 \\
\hline $360^{\circ}$ & 0.040 & 0.43 & 0.0172 \\
\hline
\end{tabular}

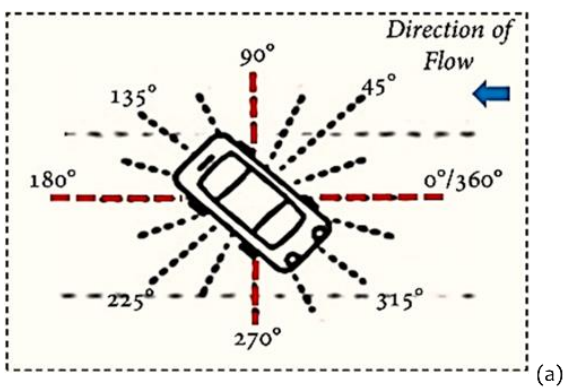

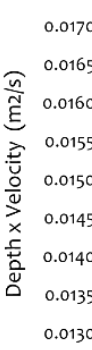

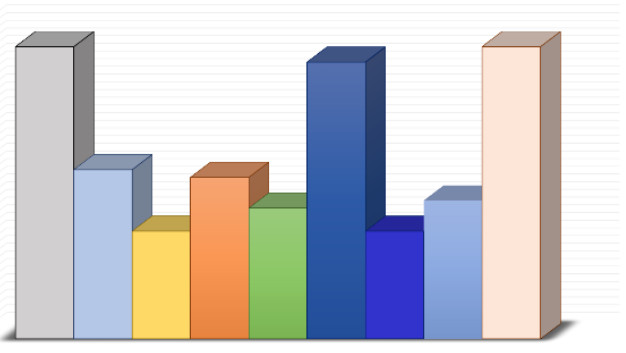

$\square 0^{\circ} \square 45^{\circ} \square 90^{\circ} \square 135^{\circ} \square 180^{\circ} \square 225^{\circ} \square 270^{\circ} \square 315^{\circ} \square 360^{\circ}$ Orientation $\left({ }^{\circ}\right)$

Figure 16 Least critical conditions (a) Orientations and (b) Lowest threshold values

\subsection{CONCLUSIONS}

In the course of this investigation, modes of vehicle instability, namely floating and sliding instability were studied. The literature suggests that mode of floating instability governs in high water depths when the vertical pushing forces i.e. the up-thrust and lift forces exceeds vehicle weight. Herein, the study was performed under sub-critical flow conditions thus, the influence of lift force was disregarded. (1) Therefore, it can be proposed that the mode of floating instability occurred when the water depth exceeded $0.042 \mathrm{~m}$. Above critical water depth, the influence of buoyancy force on the submerged volume of the car exceeded vehicle weight. (2) Conversely, mode of sliding instability was witnessed below the critical water depth at the limiting values of depth $x$ velocity $\left(D^{*} V\right)$. This mode of instability was found dominant when the flow velocity was high and the water depth was low. (3) Prior to conducting the experiments, proper surface roughness of the platform was determined so that influence of friction force between the tires and road surface can be ensured. (4) It was further noticed that the vehicle was most stable when positioned at the orientation of $0^{\circ} / 360^{\circ}$ because of the low drag impact at the frontal area of the vehicle. (5) On the other hand, the vehicle was found to be least stable when positioned at $90^{\circ}$ and $270^{\circ}$ as the threshold of sliding instability occurred at small $D^{*} V$ values. At this orientation, the projected area available to the flow direction was greater thus, the impact of drag was found maximum. (6) Based on study outcomes some safety guidelines have been proposed by highlighting the least threshold $\mathrm{D} * \mathrm{~V}$ values for the vehicles at different orientations. However, it is believed that further research, 
preferably at prototype scale is required as there are still numerous issues to be considered while conducting such studies. Among the main issues, it includes, proper estimation of friction, lift and drag coefficients. Moreover, the assessment of the flooded vehicles under more complex and real situations need to be carried.

\section{Acknowledgement}

The author is grateful to the supervisors and the lab specialists for their persistent support and is thankful to Universiti Teknologi PETRONAS for the Graduate Assistantship.

\section{References}

[1] Parker, D. J. 2000. Floods - Volume I. Taylor \& Francis Group.

[2] Fleming, G. 2002. Flood Risk Management: Learning to Live with Rivers. Thomas Telford. DOl:http://www.icevirtuallibrary.com/doi/book/10.1680/fr mltlwr.31128.

[3] Smith, G. 2015. Expert Opinion: Stability of People, Vehicles and Buildings in Flood Water. WRL Technical Report 2015/11, Water Research Laboratory, University of New South Wales. Sydney, Australia. DOI: 10.4225/53/58eldfd63flf4.

[4] Versini, P. A., Gaume, E., \& Andrieu, H. 2010. Assessment of the Susceptibility of Roads to Flooding based on Geographical Information-test in a Flash Flood Prone Area (The Gard Region, France). Natural Hazards and Earth System Sciences. 10: 793-803. DOI:http://www.nat-hazardsearth-syst sci.net/10/793/2010/doi:10.5194/nhess-10-7932010.

[5] García, C. C., \& Lorenzo, R. G. 201 1. Flood Hazard Factors and Indexes for Road Stream Crossings in Ephemeral Channels. Study Applied to the Coastal Southern Area of the Murcia Region. Boletín de la Asociación de Geógrafos Españoles N. 57: 433-438.

[6] Mok, O. 2017. Vehicle Stuck in the Flood at Jalan Air Itam in George Town. News Report: The Malay Mail Online. Available:http://www.themalaymailonline.com/malaysia/ article/flash-floods-hit-penang-rivers-at-dangerouslevel\#uuq0XqtxqbOviyPE.97.

[7] Haynes, K., Coates, L., Leigh, R., Gissing, A., McAneney, J., \& Handmer, J. 2009. Shelter-in-place Versus Evacuation in Flash Flood Environments. 49th Annual Floodplain Management Authorities Conference and 6th Biennial Victorian Flood Conference', Albury, Australia, 2009. 17-20. DOI:http://www.tandfonline.com/doi/abs/10.3763/ehaz.2 009.0022.

[8] Teo, F. Y., Xia, J., Falconer, R. A., \& Lin, B. 2012. Experimental Studies on the Interaction between Vehicles and Floodplain Flows. International Journal of River Basin Management. 10: 149-160. DOI: http://dx.doi.org/10.1080/15715124.2012.674040.

[9] Xia, J., Falconer, R. A., Xiao, X., \& Wang, Y. 2014. Criterion of Vehicle Stability in Floodwaters based on Theoretical and Experimental Studies. Natural Hazards. 70: 1619-1630. DOI: https://link.springer.com/article/10.1007/s1 1069-0130889-2.

[10] Subramaniam, S. K., VIGNESWARA, R. G., Subramonian, S., \& Hamidon, A. H. 2010. Flood Level Indicator and Risk Warning System for Remote Location Monitoring using Flood Observatory System. WSEAS Transactions on Systems and Control. 3(5):153-163.
[11] Jonkman, S. N., \& Kelman, I. 2005. An Analysis of the Causes and Circumstances of Flood Disaster Deaths. Disasters. 29(1): 75-97. DOI: 10.1111/j.0361-3666.2005.00275.x.

[12] Petrucci, O., \& Pasqua, A. 2012. Damaging Events Along Roads during Bad Weather Periods: A Case Study in Calabria (Italy). Natural Hazards and Earth System Sciences. 12: 365-378. DOI: http://www.nat-hazards-earthsyst-sci.net/12/365/2012/doi:10.5194/nhess-12-365-2012.

[13] Wallingford, H. 2006. Flood Risks to People: Phase 2. FD2321/TR2. Defra /Environment Agency, Flood and Coastal Defence R\&D Programme. Available: www.defra.gov.uk/environ/fcd/research.

[14] Balke, K., Higgins, L., Chrysler, S., Pesti, G., Chaudhary, N., \& Brydia, R. 2011 . Signing Strategies for Low-Water and FloodProne Highway Crossings. Texas Transportation Institute, The Texas A\&M University System College Station, Texas 778433135.

[15] Ruin, I., Creutin, J. D., Anquetin, S., Gruntfest, E., \& Lutoff, C. 2008. Human Vulnerability to Flash Floods: Addressing Physical Exposure and Behavioural Questions. Flood Risk Management: Research and Practice Proceedings of the European Conference on Flood Risk Management Research into Practice, Oxford, UK, 30 September-2 October 2008. 1005-1012.

[16] Steve, W. 2012. Forces on Vehicles Crossing Streams [Online]. Flood Control District of Maricopa Country: Flood Warning/Water Quality Branch Engineering Division. Available:www.nws.noaa.gov/os/water/tadd/pdfs/Water Physics.pdf.

[17] Martínez-Gomariz, E., Gómez, M., Russo, B., \& Djordjević, S. 2017. A New Experiments-based Methodology to Define the Stability Threshold for Any Vehicle Exposed to Flooding Urban Water Journal. DOl: http://dx.doi.org/10.1080/1573062X.2017.1301501.

[18] Shu, C., Xia, J., Falconer, R. A., \& Lin, B. 2011. Incipient Velocity for Partially Submerged Vehicles in Floodwaters. Journal of Hydraulic Research. 49: 709-717. DOI: http://dx.doi.org/10.1080/00221686.2011.616318.

[19] Shand, T., Cox, R., Blacka, M., \& Smith, G. 2010. Appropriate Safety Criteria for Vehicles. Australian Rainfall and Runoff, Stage 2 Report: P10/S2020.

[20] Bonham A., \& Hattersley, R. T. 1967. Low Level Causeways. Available: $\mathrm{http}: / /$ trove.nla.gov.au/version/25374854.

[21] Gordon, A., \& Stone, P. 1973. Car Stability on Road Floodways. National Capital Development Commission, 1973. Available: http://trove.nla.gov.au/version/11595217.

[22] Keller, R. J., \& Mitsch, B. 1993. Safety Aspects of the Design of Roadways as Floodways. Urban Water Research Association of Australia Melbourne, Australia.

[23] Mens, M. 2008. Frameworks for Flood Event Management. Integrated Flood Risk Analysis and Management Methodologies, Report Number: T19-07-04. Available: repository.tudelft.nl/islandora/object/uvid:Oabal8f1-9ac241 cc-abea.../download.

[24] Cox, R., Shand, T., \& Blacka, M. 2010. Appropriate Safety Criteria for People. Australian Rainfall and Runoff, Revision Project 10: PIO/SI/006.

[25] Teo, F. Y. 2010. Study of the Hydrodynamic Processes of Rivers and Floodplains with Obstructions. Thesis Submitted for Doctor of Philosophy. Available: http://orca.cf.ac.uk/id/eprint/54161

[26] Xia, J., Teo, F. Y., Lin, B., \& Falconer, R. A. 2011. Formula of Incipient Velocity for Flooded Vehicles. Natural Hazards. 58: 1-14. DOI: 10.1007/s1 1069-010-9639-x.

[27] Kalid, K. I. B. 2005. Experimental Studies of Flow Over Flip Bucket. Final Year Project Report, B.Sc in Civil and Environmental Engineering, Universiti Teknologi PETRONAS, Malaysia.

[28] Te Chow, V. 1959. Open Channel Hydraulics. McGraw-Hill Book Company, New York. xviii +680 .

DOI: 10.1126/science.131.3408.1215-a

[29] Teo, F. Y., Falconer, R. A., Lin, B., \& Xia, J. 2010. Investigations of Hazard Risks Relating to Vehicles Moving in Flood. Journal of Water Resources Management. 1: 52-66. 
[30] Falconer, R. A., Lin, B., \& Xia, J. 2012. 2D Hydrodynamic Modelling: Mobile Beds, Vehicle Stability and Severn
Estuary Barrage. Flood Risk Management Research Consortium. Project Website: www.floodrisk.org.uk 